Actes des congrès de la Société française

Shakespeare 450

\title{
Elsinore - Berlin: Hamlet in the Twenties
}

\section{Andreas Höfele}

\section{(2) OpenEdition}

\section{Journals}

Electronic version

URL: http://journals.openedition.org/shakespeare/3033

DOI: 10.4000/shakespeare.3033

ISSN: 2271-6424

\section{Publisher}

Société Française Shakespeare

Electronic reference

Andreas Höfele, "Elsinore - Berlin: Hamlet in the Twenties ", Actes des congrès de la Société française Shakespeare [Online], 33 | 2015, Online since 10 March 2015, connection on 02 June 2020. URL : http://journals.openedition.org/shakespeare/3033 ; DOI : https://doi.org/10.4000/shakespeare.3033

This text was automatically generated on 2 June 2020 .

(c) SFS 


\title{
Elsinore - Berlin: Hamlet in the Twenties
}

\author{
Andreas Höfele
}

\section{I}

1 On April 11, 1919, five months to the day after the Armistice at Compiègne, readers of The Athenaeum found a revenant Hamlet surveying the spiritual aftermath of the Great War:

From an immense terrace of Elsinore which extends from Basle to Cologne, and touches the sands of Nieuport, the marshes of the Somme, the chalk of Champagne, and the granite of Alsace, the Hamlet of Europe now looks upon millions of ghosts. [...]

If he picks up a skull, it is a famous skull. Whose was this? This was Leonardo. He invented the flying man; but the flying man has not exactly served the intentions of the inventor. [...] And this second skull is Leibniz, who dreamed of universal peace. And this was Kant, who begat Hegel, who begat Marx, who begat...

Hamlet hardly knows what to do with all these skulls. But if he leaves them! ... Will he cease to be himself? His terribly clairvoyant mind contemplates the transition from war to peace. This transition is more obscure, more dangerous, than the transition from peace to war. All the peoples are troubled by it. And I, he says, I, the European intellect, what shall I become? And what is peace? Peace is perhaps the condition of things in which the natural hostility of man to man is expressed in creations instead of in the destructions that war engenders. It is the period of creative competition, and the struggle of productions. But I, am I not tired of producing? [...]

Farewell ghosts! The world needs you no longer, nor me. The world, which calls by the name of "progress" its tendency towards a fatal precision, marches on from Taylorization to Taylorization. Still a certain confusion reigns, but it will soon be cleared away, and we shall see appear a miracle of animal society, a perfect and final antheap. ${ }^{1}$ 
This passage concludes the first of two 'Letters from France' which John Middleton Murry, The Athenaeum's editor, had commissioned from Paul Valéry. The war is over but the time is clearly out of joint. Peace, Valéry suggests, may prove the more problematic condition, especially after this war. Valéry's Hamlet, representing the European intellectual, is not merely unable to cope with an over-heavy task, he no longer knows what the task might be or even if there is a task at all.

3 Valéry's 'Letter' opens with: "We civilizations now know that we are mortal". Mortal like the long-gone civilizations of Elam, Niniveh and Babylon, whose "total ruin [...] meant as little to us as their existence." ${ }^{2}$ But the ruin of modern Europe conflates those ancient disasters with the present catastrophe: "Thus the spiritual Persepolis is ravaged equally with the material Susa. All is not lost, but everything has felt itself perish."

4 Two years later another contributor to The Athenaeum ${ }^{3}$ drew the same long-distance parallel in what was to become the most famous $20^{\text {th }}$-century poem in English:

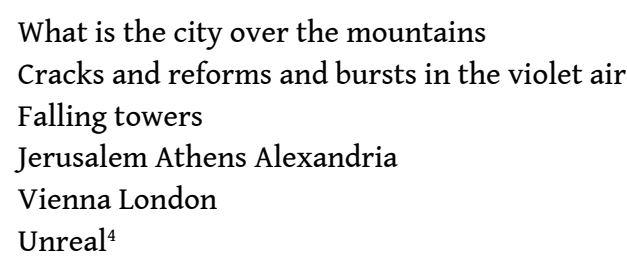

T.S. Eliot no doubt knew and approved of Valéry's Athenaeum article; just as Valéry, in making Hamlet the incarnation of the European intellect, was no doubt aware of the long-standing, highly fraught identification of Hamlet with the intellect - or the mind, or the spirit - of one particular European country, Germany. "Deutschland ist Hamlet" was the opening line of a poem written in 1844 , in which the liberal nationalist Ferdinand Freiligrath bitterly castigates his own and his countrymen's inaction in the face of an oppressive political regime. "Germany is Hamlet" caught on as a catchphrase in which self-reproach became uneasily entwined with national pride. ${ }^{6}$

Valéry's conceit supplants and incorporates this identification. As he picks up the skulls of German thinkers, Valéry's European Hamlet ponders the transience of an intellectual tradition in which he, Hamlet, had figured as an identificatory icon. But in pondering his own obsolescence and the obsolescence of the culture that sustained him, Hamlet is also attesting to his undiminished timely relevance. With his trademark skull, he is, after all, the most readily identifiable memento of mortality in the European imaginary and thus never more called for than when there are millions of ghosts and a civilization in ruins. In 1919, Hamlet's "Embassy of Death", to quote Wilson Knight's famous 1930 essay $^{7}$, was far from over. It was just going into a new phase.

6 The Great War had revoked Germany's entitlement to the role of Hamlet and recast her, as Henry Arthur Jones wrote in 1916, as a bloodthirsty Macbeth. ${ }^{8}$ But Shakespeare's melancholy prince continued to haunt troubled minds in the troubled Republic that succeeded the demise of the Wilhelminian Empire. For the political right wing, Germany's defeat in 1918, the "shame peace" of Versailles and the despised parliamentary system of the Weimar Republic widened the chasm between Germany as it actually was and Germany as the rightists thought it should be. The slogan "Germany is Hamlet" had originally drawn its political edge from just such a disparity between 
the actual and the ideal state of the nation. It now acquired an increased topical urgency.

7 Carl Schmitt, the rising professor of law and political theorist who later became notorious as "Hitler's crown-jurist", noted in his diary of December 1, 1923: "Germany is Hamlet - unfortunately no longer." And Joseph Goebbels, one-time student of the famous Jewish professor Friedrich Gundolf, author in 1911 of a bestseller that had celebrated the union of Shakespeare and the German Spirit, poured out his frustrations in a third-rate confessional novel. Its title hero, Michael, a gushing hybrid of Hamlet and Goethe's Werther, exclaims: “Old Europe is going down the drain. Yes, it's a mad world! Thrift, thrift, Horatio!"10

\section{II}

Berlin held a rather special place among the Babylons and Ninivehs of post-war Europe. It epitomized the crisis of modernity, but also the unparalleled upsurge of cultural energies set free by that crisis during Germany's first, short-lived democratic period. The period was incongruously named after provincial Weimar, but its centre of gravity, culturally no less than politically, was, of course, Berlin. The name Weimar stood for the hope of a new beginning in the spirit of Goethe rather than Bismarck. But the prime reason for holding the constituent national assembly in the theatre at Weimar was because Berlin simply was not safe. ${ }^{11}$

In the event, Berlin never did become quite safe for the Republic. Even in the relatively prosperous middle years of the decade, when the Twenties were starting, even in Germany, to be called "golden", the metropolis remained a hotbed of violent political controversy. Not long before the Wall Street Crash of 1929, when the liberal foreign secretary Gustav Stresemann said that Germany was "dancing on a volcano", he was referring to the economy; but the metaphor was soon seen to epitomize the sensibility, lifestyle and mood of a whole generation. ${ }^{12}$

10 Valéry's Hamlet or the Tiresias of Eliot's Waste Land could not have found a more suitable stage for their cultural pessimism than 1920s Berlin. Where was tradition more recklessly challenged, the disruptive forces of modernity more keenly felt and more eagerly fuelled than here? Berlin afforded an exemplary instance of what Eliot described as "the immense panorama of futility and anarchy which is contemporary history". ${ }^{13}$ But widespread as it was, especially among the German bourgeoisie, cultural pessimism was, of course, not the only possible response to the post-war condition. "Progress", that favourite hate-word of the intellectual right, held out genuine hope for all who felt the past was anything but a paradise lost.

11 Hamlet, it would seem, was more naturally aligned with a backward-looking rhetoric of loss, the yearning for an unrecoverable past, a past that never really existed except as the ghost of a heroic fantasy. Supporters of the popular stab-in-the-back legend could read a Hamletian pattern into the recent course of events, seeing Germany's defeat and the abdication of the Kaiser as due not to Allied military victory but to the November 1918 revolt of the German armed forces and its leftist instigators. Murder most foul, in other words, and crying out for revenge. The legitimate old order had been treacherously overturned by the so-called "November criminals", the father-monarch 
replaced by a breed of latter-day Claudiusses, "cutpurses of empire and rule", mockkings "of shreds and patches". ${ }^{14}$

In the remainder of this paper I will look at two versions of Hamlet that resist this reactionary slant. Both align the play with modernity, albeit in widely different ways. Both, I argue, draw a good deal of their power from their infraction of the German Hamlet tradition and its latently anti-modern drift in which "the very age and body of the time" could so plausibly find "his form and pressure" (Hamlet III.ii.21-22). My first example is the 1920/1921 film Hamlet: Drama of Revenge directed by Svend Gade and Heinz Schall with the Danish actress Asta Nielsen in the title role. ${ }^{15}$ The other is Leopold Jessner's 1926 production of Hamlet at the Prussian State Theatre, in which Fritz Kortner played the prince. The Gade-Nielsen film and the Jessner-Kortner theatre production are arguably the two most unorthodox Hamlets of the Weimar period. And in being that they are also by far the two most important ones.

\section{III}

Hamlet: Drama of Revenge was Asta Nielsen's fifty-second film since she began her movie career in 1910 but the first produced by her own company, Art-Film. ${ }^{16}$ Nielsen was thirty-nine when the film was shot in Berlin in the summer of 1920 and an international - or rather, the international - film star. Worshipped by the men in the trenches on both sides, she was anything but conventionally "beautiful": "Her enormous dark eyes, thin lips, masklike face, and slender, boyish figure contrast[ed] starkly with prevailing female body norms", ${ }^{17}$ especially those prevailing in the American film business. The Variety commentator sourly remarked after seeing the American premiere of Nielsen's Hamlet:

Miss Neilson's [sic!] abilities are exceptional, but they are not the type to enrapture the American public. Almost emaciated, she has command and distinction of movement. Her facial pantomime is of considerable range, but dead whites and blacks have to be used to overcome her physical deficiencies. ${ }^{18}$

Most other commentators on either side of the Atlantic saw the very opposite of "deficiencies: She is "the drunkard's vision and the lonely man's dream", Guillaume Apollinaire wrote in a tribute ${ }^{19}$ that sounds more than a little like Walter Pater's famous eulogy on the Mona Lisa, whose beauty "[a]ll the thoughts and experience of the world have etched and moulded". ${ }^{20}$

Rather than conforming to existing styles, Nielsen created her own. Her androgynous appearance, which prior to Hamlet had been foregrounded in several comic breeches parts and was often emphasized by her trend-setting Bubikopf (gamine/bob) hairstyle, made her an iconic embodiment of the working, independent New Woman. ${ }^{21}$ She was as much a role model for female spectators as an object of male fantasies.

When this Mona Lisa of the silent screen took on the Mona Lisa of literature, her version of Hamlet boldly supplied what T. S. Eliot found so regrettably missing in Shakespeare's play: an appropriate "objective correlative" for Hamlet's bottomless grief. ${ }^{22}$ In the Nielsen film 
Hamlet is [...] a woman passed off by her mother as a boy in order to secure the succession. All conflicts arise from this. Hamlet must play a false game throughout, hiding his deepest heart's desire for his friend [Horatio]. ${ }^{23}$ indeed could be more tragic! The idea for this quirky take on the Hamlet story came from the crackpot labour of love of an American amateur Shakespearean, Edward P. Vining. The Mystery of Hamlet (1881) is one of those wonderfully wacky attempts at a once-and-for-all solution where centuries of learned precursors have stumbled clueless in the dark. Why does Hamlet talk so much rather than act, why is he so impulsive, prone to tears and dissimulation, why so prissily nauseated by Yorick's skull and so afraid of death, why so ungallantly harsh towards Ophelia, but loving towards Horatio? These and a host of other traits, Vining decides, "are far more in keeping with a feminine than with a masculine nature". ${ }^{24}$ The prince, in other words, must be a princess in disguise, not just a "womanly man" but "in very deed a woman, desperately striving to fill a place for which she was by nature unfitted." ${ }^{25}$

Frmly grounded in the gender stereotypes of his day and convinced that a man in love with another man can only be a woman, ${ }^{26}$ Vining's theory ironically enabled Nielsen to subvert the very foundations on which this theory was built. Nielsen's Hamlet mercurially crosses and re-crosses gender boundaries, "destabiliz[ing] the polarized opposition between masculine and feminine identities." ${ }^{27}$ The Vining-based script, for all its "melodramatic absurdity", ${ }^{28}$ thus becomes an ideal vehicle for Nielsen's performance of gender-as-performance, as she (quoting Judith Buchanan) "adopts selfconsciously manly poses to delude her on-screen (and entertain her off-screen) public." ${ }^{29}$ Unlike all her female predecessors in the part from Sarah Siddons to Sarah Bernhardt, Nielsen does not impersonate a man. She plays a woman impersonating a man. This adds a complexity to the part that owes little to Shakespeare but speaks strongly to the concerns of the time. As Tony Howard points out, Nielsen's "Hamlet was a study of young people reinventing gender roles in the aftermath of war and its explosion of patriarchal tradition. [...] [H]er film condemns everyone, female or male, who collaborates with reactionary structures of gender and power." 30

But this does not mean that the forces of the young, vibrantly centred in Nielsen's Hamlet, are allowed to prevail. The film alternates (again quoting Howard) "between scenes of Hamlet performing, where she is all-powerful, and sequences where she is trapped alone by shadows and stones." ${ }^{11}$ Thus Hamlet, as in Saxo Grammaticus, resolutely traps and kills Claudius in a fire but still ends up trapped herself by the machinations of an unprecedentedly evil Gertrude who is entirely of the script-writer's invention. The film closes "over her dead body" right after Horatio finally discovers his friend's secret by accidentally touching her breast: "Only death reveals your secret to me. Your golden heart was that of a woman. Too late - beloved - too late."

This is certainly not Shakespeare, but neither was it meant to be. "The film Hamlet", Erwin Gepard declared, "has only parts of the subject matter and a few characters in common with Shakespeare. In no way is it a reworking of the Shakespearean drama." ${ }_{32}$ Gepard should know: he wrote the screenplay. His authorial hand has so far been either ignored or belittled. ${ }^{33}$ Erwin Gepard was the pseudonym "behind which", as a contemporary film journal confided to its readers, "one of the most controversial expressionist poets is hiding." ${ }^{34}$ This was Franz Richard Behrens, author of Blood Blossom

Actes des congrès de la Société française Shakespeare, 33 | 2015 
(Blutblüte) $^{35}$, a volume of radically experimental war poems published in 1917 while the author was a soldier on the Western front. After the war, Behrens worked as a journalist and screen-writer. His last poem appeared in 1925, and he was subsequently so entirely forgotten that people thought him long dead when his poetry was rediscovered in the 1970s. There is now a four-volume edition of his works, the last volume containing his film criticism and his screenplays, including Hamlet. ${ }^{36}$

Gepard's disclaimer defined Nielsen's PR strategy throughout. The news that she was planning to make a Hamlet movie had caused some negative advance publicity. There had been talk of "Shakespeare forgery". The way to deflect this was to declare that her Hamlet was not Shakespeare's but a "Drama [...] after motifs of the Hamlet Saga discovered by Professor Vining". Vining did eventually become a professor - though not of English literature - but he had certainly not discovered the saga, recorded by Saxo Grammaticus, on which Gepard draws for the death of Claudius.

With his unorthodox treatment of Hamlet under the protective cloak of one professor, Gepard took the liberty of railing at all others. In a Prologue which did not make it into the film he has a "big crowd of grave professors with beards and glasses" demonstrate their disapproval in front of a cinema, then engage in a battle over the true meaning of Hamlet in a lecture hall. Their turbulent dispute is cut short by the appearance of Shakespeare himself. The script has him turn in his grave, then rise from it and present himself at the lectern:

He yawns, stretches, knocks over all the books. The professors scatter in all directions. Shakespeare stands smiling in all his vigour. He fades out. Hamlet's dreamy head emerges from the fading Shakespeare. ${ }^{37}$

Then Hamlet breaks into soliloquy, borrowing Macbeth's: "Life's but a walking shadow", etc. All that survives of this prologue in the film are the eight opening title cards citing Voltaire, Herder, Goethe and, of course, Vining with the final verdict: " Hamlet war in Wirklichkeit ein Weib!" "Hamlet was in reality a woman!"

Gepard's professor-bashing may seem no more than a schoolboy joke, a mere diversion from the film's more serious concerns. But it is symptomatic of the film-makers' general attitude towards established authority. Silly as it may seem, it makes a claim of entitlement, raising - and answering - the question as to who owns Hamlet. Certainly not those who have always owned him or thought they did. This message is even more emphatically delivered in Gepard's essay "To my best friend - Hamlet":

People ask me every day: "How can you presume to rewrite Hamlet for film?" Because I love Hamlet! Because he is my best friend! [...] I want to show Hamlet, this figure of universal empathy [...] to people of all nations [...]. Today there is only one medium that can make everyone on earth feel touched by Hamlet: film! - And because there is only one person today who can represent Hamlet, that person is a woman and her name is: Asta Nielsen! Storms of outrage broke out among the philistine guardians of art and culture when this idea first surfaced. Hamlet - the immortal masterpiece [...] not only reworked but [...] played by a woman? ${ }^{38}$

Gepard surely overdramatizes the advance hostility to Nielsen's project. But his claim for a universally popular Shakespeare with die Asta as its iconic embodiment is authentic. He emphatically reiterates it in his "Asta-Ode" (1923), a 600-line Nielsenfilmography in verse: 


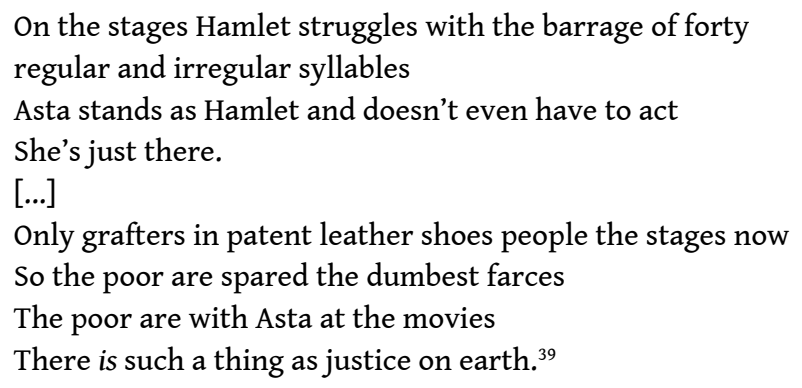
interiors were shot in a converted aircraft factory and, as one critic somewhat wistfully remarked, the drapings of the great hall at Elsinore were made from the wing coverings of German Albatros fighter planes. ${ }^{40}$ The opening battle between Denmark and Norway recalls images of modern trench warfare rather than chivalric heroism. Old Hamlet is not a towering paternal ghost but a faltering war invalid. And when Hamlet meets Fortinbras at Wittenberg, their decision to forget their fathers' enmity resonates with the founding spirit of the League of Nations. All this has been observed before. It gains some additional depth when we consider that the script was written by a man whose first published poem, under the title "Expressionist Artillerist", appeared during the battle of Verdun. He was one of those for whom the downfall of the old order did not spell the death of civilization but the hope of a new beginning.

\section{IV}

The same is true of Leopold Jessner. And his is also an exemplary case of how fragile that hope was. Jessner's appointment as head of the Prussian State Theatre in 1919 marked a radical break with tradition. He was a Jew and a Social Democrat. The always latently and often openly anti-Semitic conservative press noted that, with his appointment, the "Jewification" of the Berlin theatres was complete. The former Court, now State Theatre had been the last one headed by a gentile "Intendant". ${ }^{41}$ It had been the representative theatre of the old order, its repertoire and style of production reflecting the rigidly conventional taste of the Prussian court. ${ }^{42}$ Jessner converted this stronghold of Wilhelminian culture into the representative stage of the new republic. For a short while - no more than four or five years - his work defined the cutting edge of modernity in the theatre.

When Jessner chose Schiller's Wilhelm Tell for his opening production, this seemed to signal a continuation of the old Court Theatre tradition. But even as the curtain rose revealing an abstract-sculptural set instead of the customary cardboard mountains, the new direction became clear. Unprecedented tumult broke loose in the audience when Fritz Kortner stormed on stage in the role of Tell's antagonist Gessler. Dressed in a black uniform bedecked with military medals, he slapped his polished knee boots impatiently with a riding crop: an obvious caricature of Wilhelminian militarism or, as Kortner writes in his autobiography, a premonition of Hitler's vain Reichsmarschall Göring.

Such direct satirical jabs, however, were the exception, not the rule in Jessner's style. His landmark Richard III, which ran almost simultaneously with Asta Nielsen's Hamlet, emphasized Shakespeare's modernity by placing the rise and fall of the villain on an

Actes des congrès de la Société française Shakespeare, 33 | 2015 
abstract "timeless" stage, dominated by a monumental flight of stairs. This is reminiscent, or rather, "preminiscent", of Ian Kott's "great staircase" of history. Jessner also anticipated Kott in approaching Shakespeare as a contemporary. ${ }^{43}$ " Zeitausdruck" is the term he used to define his aims: combining elements of timeless simplicity with an unmistakably modern consciousness. Instead of the escapist theatre magic of a Max Reinhardt, Jessner offered "the abstract and brief chronicle of the time" (Hamlet, II.ii.504). Audiences were overwhelmed by the driving pace of Jessner's productions, a dynamism strikingly embodied in his most important lead actor, Fritz Kortner.

Their collaboration was never without tension. The Hamlet of 1926 marked their reunion after an interval of several years. But quite contrary to expectation, Kortner did not dominate this production in the way he had dominated Richard III. Jessner was simply not interested in the psychology of Hamlet. That, he said, had been treated exhaustively in so many scholarly studies and by so many excellent actors that "the grammophone record of 'To be or not to be' has become worn. The prince's melancholy has become proverbial and thus a cliché." ${ }^{44}$ Neither was he interested in just another trendy modern-dress "Hamlet in Tails" (Hamlet im Frack). Two of those were on show at the time: one in Hamburg and one in Vienna, a German version of H. K. Ayliff's Birmingham Repertory production featuring Reinhardt's star actor Alexander Moissi. Jessner's modernity was not confined to new clothes. ${ }^{45}$ His take on the play centred on the sentence: "There is something rotten in the state of Denmark."

Jessner's rotten state of Denmark was a sombre, draughty, crumbling palace with many suspiciously creaking doors, the appropriate setting for a production focusing on the distrust spawned by corruption. Hamlet's watchful enemies lurk everywhere, the doors constantly in motion, opening and closing, revealing and hiding the King's spies. Then, in the third act, a curtain opened revealing the galleries and boxes of a splendid baroque style theatre in which Claudius and his court watch "The Murder of Gonzago". This meticulously realistic set-so unlike Jessner's usual abstractions-received a spontaneous round of applause from the astonished audience. Jessner's designer, Caspar Neher, had resurrected the old Court Theatre for the play within the play, a theatre within the theatre. Past and present, monarchy and Republic, faced each other across the footlights. ${ }^{46}$

29 The play's topical relevance was emphasized throughout. Laertes' revolt against Claudius was staged as a modern coup d'état. Fortinbras' troops do not march across an empty plain but disembark from a battleship in a gloomy harbour dominated by a lighthouse. After Hamlet's death Fortinbras rattles off his final declarations like a Prussian officer in the same room of the palace where Claudius had addressed his first lines to his court (I.ii.1ff). Decades ahead of Jan Kott (and innumerable productions influenced by him) Jessner showed history to be caught in a vicious circle.

30 The production was a highly controversial satire on the old monarchy and, indirectly, an attack on the anti-Republican forces of the right. ${ }^{47}$ One detail particularly incensed the conservatives. After the mousetrap scene, the actor playing Claudius dangled his right arm as if paralyzed by a stroke. Could it be that the director of the State Theatre had the bad taste to poke fun at the last Kaiser's similar handicap? Not for the first time did nationalist members of the Prussian Diet demand Jessner's resignation. His denial met with disbelief. The necessity to counter attacks like this increasingly absorbed Jessner's energy. 

Although individual traits were brought out brilliantly, the character as a whole seemed to lack coherence. Unlike the film, where everything hinged on Nielsen's mesmerizing performance, Jessner's stage Hamlet was found wanting precisely such a centre of gravity. The state of Hamlet clearly mattered less than the state of Denmark. This was a Hamlet not exactly without the prince, but with a prince reduced in just about everything, including tragic pathos.

Few reviews, and not only the hostile ones, failed to allude to Kortner's Jewishness. Felix Hollaender, a Jewish critic much impressed by the production as a whole, described Kortner's Hamlet as a mix of "Tartuffe and Talmud pupil" and, despite "his straw-blond hair", "more like a Hebrew scribe than a Danish prince". ${ }^{48}$ The blond wig worn by Kortner became such a bone of contention that a passage from Goethe was added to the printed programme in which Wilhelm Meister claims that we must imagine Hamlet as "fair-haired and plump" because a "slim, brown-locked youth" could be expected to be more resolute. ${ }^{49}$

But that the Jew Jessner could cite Goethe for his purpose did not make him any less objectionable than Shylock citing Scripture to the Venetians. Here was Hamlet, the Nordic prince whom Germans had traditionally seen as embodying their own national character, played by an actor whom the right-wing press had typed as the epitome of "Jewishness" This aroused latent resentments even in the "respectable" press. In the Nazi papers it exploded into outright vituperation:

Take a look at that Kortner's face: [...] Ibsen's Oswald and Shakespeare's Hamlet he played with blond wig, and he nasalized his "To be or not to be" the way they [the Jews] haggle over their percentages. All the depravity the Jews have spawned in the course of thousands of years finds a perfect expression in this Cohn. ${ }^{50}$

This was written in 1930, shortly after Jessner-worn down by constant attacks -had handed in his resignation.

\section{V} Nielsen's Hamlet challenged traditional gender norms. But this challenge apparently gave no offence to anyone, quite unlike Jessner's production. A Jewish Hamlet donning the blond wig derived from Goethe had an infinitely greater scandal potential than a Danish actress's gender-bending androgyny. Friend and foe alike, the reviews of Jessner's Hamlet were either openly political or bristling with the tension of political 
undercurrents. Such tension is entirely absent from the reviews of Nielsen's film. If the guardians of culture were, as Gepard/Behrens alleges, up in arms over the female Hamlet, they grumbled silently.

One explanation for this is the vast difference in institutional status between theatre and cinema. Film was just beginning to be accepted as a legitimate art form and had nothing like the cultural prestige of the theatre, and especially this theatre. From 1926 onwards, the controversy over this central stage of the Republic turned into open battle. Jessner, like the Social Democratic party he belonged to, found himself caught between the extremists of the right and the left. He resigned his post in 1930, left Germany in 1933 and died in exile in Los Angeles in December 1945.

Asta Nielsen's film career ended with the advent of the talkies. Courted by the Nazis, she resisted Goebbels's offer of a leading role in the new government's plans for the German film industry. But the fact that she stayed on in Germany until 1937 and retained her German friendships throughout the war tainted her reputation in postwar Denmark.

After 1945, reminiscences of Jessner's style were to be found in many West German productions. Yet this "Expressionism gone cold", as Fritz Kortner, returned from exile, contemptuously called it, ran counter to Jessner's intentions. Deliberately a-political, it was a turning away from contemporary reality and from Germany's recent past towards the safety of pure art and timeless ideas. It was only around 1960, when a new generation of directors such as Peter Zadek and Peter Stein began to stage their radically de-conventionalized versions of the classics that the tradition of Jessner's innovative "theatre for the Republic" was taken up again.

But this is another story ...

\section{NOTES}

1. Paul Valéry, "Letters from France. I. The Spiritual Crisis", The Athenaeum, April 11, 1919, p. 182-184 at p. 184. The French version of Valéry's two Letters was subsequently published under the title "La crise de l'esprit" in La Nouvelle Revue Française (1919) and reprinted in Cuvres, t. I, p. 988.

2. Op. cit., p. 182.

3. T.S. Eliot, "Hamlet and His Problems", in The Athenaeum, September 26, 1919, p. 940-941. For a discussion of Eliot's Athenaeum reviews, see Mark Jeffreys, "The Rhetoric of Authority in T. S. Eliot's Athenaeum Reviews", South Atlantic Review n57, 1992, p. 93-108.

4. T.S. Eliot, "The Waste Land", 11. 371-376, in T. S. Eliot, Collected Poems 1909-1962, London, Faber and Faber, 1963, p. 77.

5. Ferdinand Freiligrath, "Hamlet”, in his Ein Glaubensbekenntnis, Mainz, Zabern, 1844.

The first of the poem's stanzas reads:

Deutschland ist Hamlet! Ernst und stumm

In seinen Toren jede Nacht

Geht die begrabne Freiheit um 
Und winkt den Männern auf der Wacht.

Germany is Hamlet! Serious and silent

Buried Freedom wanders about his gates

Every night and waves at the men of the Watch.

6. For discussions of the topic see e. g. Walter Muschg, "Deutschland ist Hamlet", Die Zeit, 24 April and 1 May, 1964; Manfred Pfister, "Germany is Hamlet: The History of a Political Interpretation", New Comparison. A Journal of Comparative and General Literary Studies n², Autumn 1986, p. 106-126.

7. George Wilson Knight, "The Embassy of Death: An Essay on Hamlet" in his The Wheel of Fire: Interpretations of Shakespearean Tragedy, London, Methuen, 1930. p. 15-50.

8. "What evil angel of their destiny tempted the Germans to choose Macbeth for their anniversary offering to Shakespeare, in this year of all others? It is the very picture of their own character marching to its ruin" (Henry Arthur Jones, Shakespeare and Germany, London, Wittingham, 1916).

9. My thanks to Gerd Giesler, editor of Carl Schmitt's hitherto unpublished diaries of 1921-1924 for bringing this quote to my attention.

10. Joseph Goebbels, Michael. Ein deutsches Schicksal in Tagebuchblättern, Munich, Franz Eher Nachf., 1929, p. 86.

11. Peter Gay, Weimar Culture: The Outsider as Insider [1968], New York, London, Norton, 2001, p. 1: "[A]s Philipp Scheidemann, the first Prime Minister of the Republic, later admitted, Berlin was not safe."

12. It is reflected in publications such as Thomas W. Kniesche, Dancing on the Volcano: Essays on the Culture of the Weimar Republic, Rochester, NY, Camden House, 1994.

13. T.S. Eliot, "Ulysses, Order and Myth" (1923), in Frank Kermode, ed., Selected Prose of T. S. Eliot, London, Faber and Faber, 1975, p. 175-178 at p. 177.

14. Cf. Hamlet, III.iv.

15. In talking about the Asta Nielsen film I am only too aware of my numerous, highly expert predecessors. These include Lawrence Danson, "Gazing at Hamlet, or the Danish Cabaret", Shakespeare Survey n 45, 1992, p. 37-51; Ann Thompson, "Asta Nielsen and the Mystery of Hamlet", in Lynda E. Boose, Richard Burt, eds., Shakespeare the Movie: Popularizing the Plays on Film, TV and Video, London, Routledge, 1997, p. 215-224; Tony Howard, Women as Hamlet: Performance and Interpretation in Theatre, Film and Fiction, Cambridge, CUP, 2007, p. 137-159; Judith Buchanan, Shakespeare on Silent Film, an Excellent Dumb Discourse, Cambridge, CUP, 2009, p. 217-240; Simon Ryle, Shakespeare, Cinema and Desire: Adaptation and Other Futures of Shakespeare's Language, London, Palgrave Macmillan, 2010, p. 129-174.

16. The film exists in several different versions. I have used the restored colour print version of the film prepared by the Deutsches Filminstitut Frankfurt: Asta Nielsen. Hamlet \& Die Filmprimadonna, Edition filmmuseum 37, 2007.

17. Gary Morris, “Asta Nielsen”, in Bright Lights, $n^{\circ} 16,1996:$ http://brightlightsfilm.com/16/ asta.php, accessed 23 March 2014.

18. Leed, "Hamlet", Variety, November 11,1921. To put this verdict in perspective it helps to read the slating Rudolph Valentino's The Sheik receives on the same page. For this and many other, mostly German, press clippings I owe thanks to Christof Schöbel of the Deutsches Filminstitut Deutsches Filmmuseum, Frankfurt am Main.

19. I have been unable to trace the original quotation: Howard, Women as Hamlet, p. 144, quotes Apollinaire as quoted in Pablo Diaz, Asta Nielsen, Berlin, n.p., 1920, p. 69. It would be useful if someone identified the original locus and corroborated what Apollinaire really said.

20. Walter Pater, The Renaissance (London, 1893), Berkeley, Los Angeles, University of California Press, 1980, p. 98-99; Danson, "Gazing at Hamlet", p. 44, suggests the parallel. 
21. For a discussion of this social context Katharina von Ankum, ed., Women in the Metropolis: Gender and Modernity in Weimar Culture, Berkeley, Los Angeles, London, University of California Press, 1997.

22. T. S. Eliot, "Hamlet" (1919) in Selected Prose of T. S. Eliot, p. 45-49.

23. H. L., Review of Hamlet, Deutsche Lichtspiel-Zeitung, February 26, 1921 (my trans.).

24. Edward P. Vining, The Mystery of Hamlet. An Attempt to Solve an Old Problem, Philadelphia, J. P. Lippincott \& Co., 1881, p. 48. That the film actually plucks out the heart of the Hamlet mystery by making us sharers of her secret is observed by Ryle, Shakespeare, Cinema and Desire, p. 140.

25. Vining, The Mystery of Hamlet, p.59. Vining made it not only into the footnotes of Ernest Jones's Hamlet study but also into Stephen Dedalus' "dissertation on Shakespeare" in Chapter 6 of James Joyce's Ulysses, where we find not only that "Vining held that the prince was a woman" but also the observation that "Shakespeare is the happy hunting ground of all minds that have lost their balance" (James Joyce, Ulysses, Jeri Johnson, ed., Oxford, OUP, 1993, p. 190 and 239).

26. Danson, "Gazing at Hamlet", p. 42.

27. Patrice Petro, Joyless Streets: Women and Melodramatic Representation in Weimar Germany, Princeton, Princeton University Press, 1989, p. 153.

28. Howard, Women as Hamlet, p. 140.

29. Judith Buchanan, Shakespeare on Silent Film, p. 227.

30. Howard, Women as Hamlet, p. 146 and 152.

31. Ibid., p. 150.

32. Franz Richard Behrens [Erwin Gepard], "Meinem besten Freunde - Hamlet" (1920), in Gerhard Rühm and Monika Lichtenfels, eds, Mein bester Freund - Hamlet. Drehbücher, Kinotexte, Filmkritiken. Werkausgabe, Vol. 4, Edition text + kritik, Munich, 2012, p. 286-289 at p. 288.

33. Cf., for example, Howard, p. 142: “Though Gepard researched Hamlet's sources, Nielsen's inspiration was Vining [...]". This is misleading: Gepard did indeed do the research and, according to Nielsen, hit upon the "old saga according to which Hamlet was a woman". This enabled him "to present the theme in a new version" (Nielsen quoted in Renate Seydel, Allan Hagedorff, Asta Nielsen. Ihr Leben in Fotodokumenten, Selbstzeugnissen und zeitgenössischen Betrachtungen, München, Universitas Verlag, 198, p. 158).

34. Unattributed item "Aus dem Glashaus" in Film Kurier, June 24, 1920.

35. Franz Richard Behrens, Blutblüte, Berlin, Verlag Der Sturm, 1917.

36. Erwin Gepard, Hamlet, in Franz Richard Behrens, Mein bester Freund - Hamlet, Werkausgabe Bd. 4, Gerhard Rühm and Monika Lichtenfeld, eds, edition text + kritik, Munich, Richard Boorberg Verlag, 2012, p. 7-69.

37. Op.cit., p. 11.

38. There was at least one critic who deemed Gepard's reworking of Hamlet too tame rather than too daring: Willy Haas, "Hamlet", in Film-Kurier, 5 February, 1921.

39. Franz Richard Behrens [Erwin Gepard], “Asta-Ode”, in Behrens, Blutblüte (Werkausgabe, Vol. 1), 259-283 at 280-1.

40. Anon., "Von Dänemark bis in den Mond. Der Glasberg der Phantasie", Film-Kurier, 16 July, 1920.

41. This was Botho von Hülsen, an aristocrat of typically Prussian military background and rather limited artistic talent. He resigned, not long after the Kaiser himself, in 1918.

42. While the transition from naturalism and symbolism to the new expressionist drama was in full swing on the more progressive stages, the Imperial Court Theatre had still not got as far as Ibsen.

43. From the point of view of the theatre, Jessner once said, there is no such thing as a classic: "There are only hundred-year-old, fifty-year-old, and twenty-year-old poets of today" (Leopold Jessner, "Das Theater. Ein Vortrag", in Die Scene, vol 18 n 3, March 1928, p. 66-74; repr. in Leopold 
Jessner, Schriften: Theater der zwanziger Jahre, Hugo Fetting, ed., Berlin [GDR], Henschelverlag, 1979, p. 97-110 at p. 103.)

44. Leopold Jessner, "Das Theater. Ein Vortrag" (1928), in Leopold Jessner, Schriften. Theater der zwanziger Jahre, Berlin, Henschelverlag, 1979, p. 97-108 at p. 106 (my trans.).

45. My thanks to Claudia Blank, Director of the Deutsches Theatermuseum, Munich, for pointing me to these two contemporary productions.

46. For photographs of the production see https://www.ullsteinbild.com/ullstein-webshop/ workbench.html?queryWord=jessner+hamlet\&newTitle=ullstein+bild+

\%7C+Suche\%3A+jessner+hamlet\&qwAction=searchQueryWord\&viewMode=tile, $\quad$ accessed 12 September 2014.

47. The critic of the conservative Deutsche Zeitung confessed to liking some of Jessner's ideas, but strongly objected to the spirit of the whole thing.

48. Felix Hollaender, Review of Jessner's Hamlet, in 8-Uhr-Abendblatt, December 4, 1926; reprinted in: Günther Rühle, Theater für die Republik, Frankfurt am Main, S. Fischer Verlag, 1967, p. 764-767 at p. 765.

49. Johann Wolfgang von Goethe, Wilhelm Meister's Apprenticeship, Los Angeles, Aegypan Press, n.d., p. 286. The programme note was discovered by Claudia Blank, “Der ,andere' Hamlet: Ulrich Wildgruber und Fritz Kortner", in Winrich Meiszies, Claudia Blank, eds., Sein oder Nichtsein: Hamlet auf dem deutschen Theater, Leipzig, Henschel Verlag, 2014, p. 53-66 at p. 59.

50. "Bar Kochba", Der Angriff, March 27, 1930. Quoted in Matthias Brand, Fritz Kortner in der Weimarer Republik, Rheinfelden, 1981. Kortner had changed his name from Cohn to Kortner at the beginning of his acting career.

\section{ABSTRACTS}

In a famous essay of 1919 Paul Valéry has Hamlet survey the devastated Europe in the aftermath of the First World War. He invokes the familiar image of Hamlet to look at a world that has become radically unfamiliar. The two Berlin Hamlets examined in in this paper took a different approach. Asta Nielsen's Hamlet film (1920-1921), directed by Svend Gade and Heinz Schall, and Leopold Jessner's 1926 stage production defamiliarized Hamlet in order to immerse him in the currents of accelerating modernity, changing him so that he could participate in changing the world. Valéry's Hamlet, the paper argues, is a prophet of loss; theirs a bearer of promise; albeit a promise tragically thwarted in the political turbulences of the short-lived Weimar Republic.

Dans un célèbre essai de 1919, Paul Valéry fait analyser par Hamlet la situation de l'Europe ravagée par la Première Guerre Mondiale. Il a recours à la figure familière de Hamlet pour poser son regard sur un monde qui n'a plus rien de familier. Les deux Hamlet berlinois étudiés dans cet article adoptent une approche différente. Le film Hamlet d'Asta Nielsen (1920-1921), réalisé par Sven Gade et Heinz Schall, et la mise en scène de Leopold Jessner (1926) ont tous deux choisi de défamiliariser Hamlet pour le plonger dans le courant de la modernité en mouvement, de le changer pour qu'il puisse contribuer à changer le monde. Le Hamlet de Valéry est un prophète de la perte ; celui de Gade - Schall et de Jessner est porteur de promesses, même si ces promesses devaient être tragiquement étouffées dans les turbulences politiques de la brève République de Weimar. 
INDEX

Mots-clés: Hamlet, Shakespeare en Allemagne, Nielsen Asta, Jessner Leopold, République de Weimar, théâtre de Berlin

Keywords: German Hamlet productions, Nielsen Asta, Jessner Leopold, Weimar Republic, Berlin Theatre

\section{AUTHOR}

\section{ANDREAS HÖFELE}

Munich University 